\title{
In vitro Regeneration of Recalcitrant Green Gram (Vigna radiata L. Wilczek) from Immature Cotyledons for Genetic Improvement
}

\author{
Aparna Priyadarshini Patra ${ }^{1 *}$, Kailash Chandra Samal ${ }^{1}$, Gyana Ranjan Rout $^{1}$, \\ Simachal Sahu ${ }^{2}$ and Prem Narayan Jagadev ${ }^{2}$
}

\author{
${ }^{1}$ Department of Agriculture Biotechnology, College of Agriculture, Orissa University of \\ Agriculture and Technology, Bhubaneswar, Odisha-751003, India \\ ${ }^{2}$ Department of Plant Breeding and Genetics, College of Agriculture, Orissa University of \\ Agriculture and Technology, Bhubaneswar, Odisha-751003, India
}

*Corresponding author

\section{A B S T R A C T}

In the present investigation, a simple, rapid and efficient in vitro regeneration system was developed in green gram (Vigna radiata $\mathrm{L}$. Wilczek) cv. IPM-02-03 using cotyledonary explants excised from a 4 day old seedling. Organogenic calli were developed from

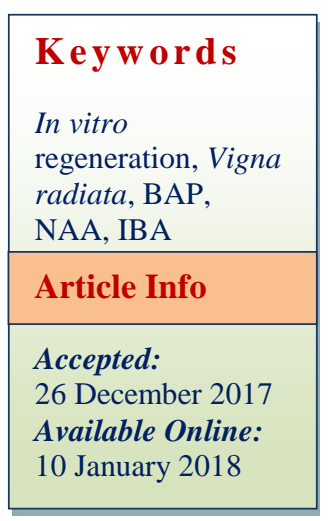
cotyledonary tissues within 4-6 weeks of culture, supplemented with $2.5 \mathrm{mg} / \mathrm{L} \mathrm{BAP}$ and $1.5 \mathrm{mg} / \mathrm{L}$ NAA. Shoot regeneration was achieved from shoot tips and cotyledonary node on MS medium was supplemented with BAP $2.0 \mathrm{mg} / \mathrm{l}$. Regeneration frequency depends on genotype, explants types and growth regulator combinations in the medium. $1.5 \mathrm{mg} / \mathrm{l} \mathrm{BAP}$ in combination with $1.0 \mathrm{mg} / \mathrm{l}$ Kinetin was proved to be the most effective treatment for multiple shoots induction from nodal explants after 3-4 weeks. The number of shoots per culture varied from 1.3 to 7.8 in different growth media. The cultures were incubated for $16 \mathrm{hrs}$ of photoperiod in $25^{\circ} \mathrm{C}$ for 2 weeks for shoot bud regeneration. The proliferated shoots were further sub cultured on similar medium for higher shoot bud regeneration. Rooting was achieved in all rooting media but elongated shoots were rooted on $1 / 2$ strength MS media supplemented with $0.5 \mathrm{mg} / \mathrm{l}$ NAA or IBA with $2 \%(\mathrm{~W} / \mathrm{V})$ sucrose which produced the maximum number of strong and healthy roots. The rooted plantlets were transferred to soil mixture (Soil: Sand: Vermicompost 1:1:1 ratio) and kept in the green house with $85 \%$ humidity. Seventy-five percent plants were successfully grown after regeneration with no phenotypic variation. This protocol can be used for genetic transformation and large-scale production of genetically improved green gram variety.

\section{Introduction}

Green gram (Vigna radiata L. Wilczek; family: Fabaceae) is an important nitrogen fixing, short duration pulse crop grown in many parts of India. It is thought to have originated from Indian sub-continent with maximum diversity at Western Ghats (De candole, 1983). It is cultivated most extensively in India, Central Asia, Central Africa, USA and Australia (Pasquet, 2001). It is an important grain legume grown mainly in arid and semi-arid situations across the country during Kharif and Rabi season and 
contributes nearly $15 \%$ of total production (Yadav et al., 2010). Green gram plays an important role in Indian diet as it contains vegetable protein and also other minerals and vitamins. It supplies easily digestible major share of protein requirement of vegetarian population of the country. The seeds contain $25-28 \%$ protein, $1.0-1.5 \%$ oil, $3.5-4.5 \%$ fiber, $4.5-5.5 \%$ ash and $62-65 \%$ carbohydrates on dry weight basis (Singh et al., 2016). Sulphur containing amino acids like methionine and cysteine were less in pulses and methionine concentration was more in urd bean and lysine content was more in mung bean. So the protein of mung bean and urd bean are an excellent to rice based diet in terms of balanced human nutrition (Singh et al., 2016).

Though India is the origin of many Vigna species but productivity is low due to biotic and abiotic stresses (Dita et al., 2006). Green gram has limited genetic variability for genetic improvement programme. A number of biotic and abiotic stresses are severely affecting the production and productivity of green gram. Novel trait can be incorporated for genetic enhancement by utilizing the trait from wild species of Vigna. The gene introgression has already resulted in enhancing the yields and disease resistance. Moreover it facilitates further genetic improvement in green gram. The gene introgression effort have led to the development of improved cultivars of green gram such as IPM-99-125, IPM-02-03 and IPM-02-14 having resistance against YMV and have increased the yield by increasing the grain size and 100 seed weight (Singh et al., 2010). An efficient and successful regeneration and transformation protocol will be the key to genetic improvement of legume but successful regeneration protocol was not well developed as it is a recalcitrant legume and tissue culture was repeatedly described to be difficult (Chandra et al., 2003; Khatun et al., 2008; Eapen, 2008; Sagare et al., 2015). A very little information is available on in vitro regeneration of green gram and its reproducibility (Khatun et al., 2008; Sen et al., 1998). Considering the above fact the present investigation was undertaken to develop a simple, efficient and reproducible protocol from nodal explants for in vitro regeneration of multiple shoots in green gram.

\section{Materials and Methods}

\section{Callus induction and shoot bud regeneration}

The seeds of green gram $(V$. radiata $\mathrm{L}$. Wilczek) cv. IPM-02-03 were collected from Centre for Pulse Research, Orissa University of Agriculture and Technology, Berhampur, Ganjam, Odisha (Figure 1a). The healthy and bold seeds were washed with distilled water and then surface sterilized with $70 \%$ ethanol (v/v) for $2 \mathrm{~min}$ followed by washing with sterile distilled water for 2-3 times. Seeds were treated with $0.1 \% \mathrm{HgCl}_{2}$ (w/v) solution for $3 \mathrm{~min}$ followed by thorough washing for 4 to 5 times with sterile distilled water to remove all the traces of $\mathrm{HgCl}_{2}$ and was blot dried on sterilized filter paper. Sterilized seeds were germinated under aseptic conditions on half-strength MS (Murashige and Skoog, 1962) medium without any growth regulators. The cotyledonary segments (cotyledonary node, hypocotyl) were excised from a fourday old seedling and cultured on modified MS medium containing various concentration of $(0,0.5,1.0,1.5,2.0,2.5,3.0 \mathrm{mg} / \mathrm{l}) \mathrm{BAP}$ or kinetin or indole-3- acetic acid (IAA) or 1napthaleine acetic acid (NAA) $(0.1,0.5,1.0$, $1.5,2.0 \mathrm{mg} / \mathrm{l}$ ) alone or in combination for callus induction and shoot bud regeneration (Table 1).

Fifteen explants were cultured per treatment and each treatment was replicated 3 times. The $\mathrm{pH}$ of the medium was adjusted to 5.7 prior to addition of agar $(6 \mathrm{~g} / \mathrm{l})$ and medium was autoclaved at $121^{\circ} \mathrm{C}$ for $20 \mathrm{~min}$. All cultures 
were kept at $25 \pm 2{ }^{\circ} \mathrm{C}$ under white fluorescent light $16 \mathrm{~h}$ photoperiod for regeneration. The subculture was made at every 4 weeks interval in the similar medium. The data was taken at every 2-3 weeks interval for regeneration frequency, number of shoot buds per culture and shoot elongation.

\section{Root induction and transplantation}

For root induction in vitro, the raised shoot (3$4 \mathrm{~cm}$ long) from MS medium supplemented with $1.0 \mathrm{mg} / \mathrm{l}$ BAP were excised and transferred to MS semisolid medium as well as liquid medium fortified with various concentrations of IAA or indole-3-butyric acid (IBA) or NAA $(0.1,0.25$ and $0.5 \mathrm{mg} / \mathrm{l})$ alone or in combination of IBA and NAA with $2 \%$ (w/v) sucrose for induction of rooting.

For efficient rooting the cultures were incubated at $25 \pm 2{ }^{\circ} \mathrm{C}$ in culture room with $16 \mathrm{~h}$ photoperiod and 3,000 lux intensity. Various biometrical observations were recorded in terms of average days to bud break, no of shoots per explant. After in vitro shooting and rooting, the plants were removed from culture tubes and were washed in running tap water to remove agar from the root. Then the rooted plantlets were kept in distilled water for two days for acclimatization under shed. After two days, the plants were transferred to earthen pots containing soil: sand: vermicompost $(1: 1: 1)$ mixture for hardening under greenhouse with $85 \%$ humidity. The data was taken at 3 weeks interval with regard to percentage of rooting, days to rooting and types of root.

All the experiments were carried out in the laboratory under completely randomized design (CRD) with three replications. The data were analyzed statistically by $\mathrm{F}$ test. F test was carried out after analysis of variance (ANOVA) and $\mathrm{CD}(\mathrm{P}=0.5)$ and $\mathrm{CV} \%$ values were calculated where $\mathrm{F}$ test was significant.

\section{Results and Discussion}

\section{Callus induction}

The results of the present investigation revealed high variation in callus induction, shoot and root regeneration. Almost 90-100\% nodal explants of green gram cV. IPM-02-03 initiated calli when cultured on modified MS media containing $0.5 \mathrm{mg} / \mathrm{l}$ BAP (Table 1). Profuse callus were induced regardless of explants used (Figure 1b). Media devoid of BAP failed to induce callus from cotyledonary nodes. It reveals that for induction of callus from cotyledonary nodes, cytokinin might be indispensible (Khatun et al., 2008). Culturing of explants on MS medium initially gave rise to creamish green callus on media containing BAP alone and nodular greenish callus was obtained when BAP was used in combination with NAA (Table 1, Fig. 1b). The callusing frequency ranged from $60-90 \%$ which seemed to depend more on concentration of BAP. The callus diameter was higher on medium containing higher concentration of BAP along with NAA and IAA (Table 1). MS media supplemented with $3.0 \mathrm{mg} / \mathrm{l}$ BAP along with NAA $0.5 \mathrm{mg} / \mathrm{l}$ have produced $92 \%$ of callus from explants. MS media supplemented with $2.5 \mathrm{mg} / \mathrm{l}$ BAP along with $0.5 \mathrm{mg} / \mathrm{l} \mathrm{NAA}$ had produced better callus having the highest diameter. Highest shoot bud regeneration from callus was found on MS media containing 2.5 $\mathrm{mg} / \mathrm{l}$ BAP. The problem of browning developed mostly in nodal explants and epicotyls derived calli. Excessive browning and root formation was observed in 4 weeks old callus culture which did not undergo subculture. Prolonged culture for 5 weeks caused severe browning and eventually death of calli. This is possibly due to accumulation of phenolic compound (Avenido et al., 1990). Culture medium without growth regulators did not show any positive effect on organogenic callus formation as well as shoot bud regeneration (Table 1). 


\section{Direct shoot and root induction}

In general in vitro regeneration of Vigna sp is more limited than other grain legume. In Vigna radiata $\mathrm{L}$. the plants are regenerated directly from explants e.g., shoot tips, cotyledonary node, primary leaf and hypocotyl. Shoot bud regeneration from cotyledonary tissues of green gram were regenerated on MS medium supplemented with various concentrations of BAP or Kinetin supplemented with NAA or IAA (Fig. 1c, 1d). There was no formation of callus and shoot bud without growth regulator in MS medium. Among the two cytokinins tested, kinetin along with BAP showed higher rate of shoot bud regeneration (Fig. 1d). Similar results have been reported by (Varalaxmi et al.,
2007). Auxin supplementation in the culture media enhanced the shoot bud regeneration. BAP in combination with NAA also enhanced the higher frequency of regeneration as compared to BAP with IBA which supported the result of Adlinge et al., (2014). Shoot regeneration was increased with increase in BAP concentration but with BAP concentrations more than $4.0 \mathrm{mg} / \mathrm{l}$ in the culture medium, the rate of regeneration was reduced. The maximum frequency of regeneration $(72.4 \%)$ was achieved on MS medium supplemented with $2.0 \mathrm{mg} / \mathrm{l} \mathrm{BAP}$ and $1.5 \mathrm{mg} / \mathrm{l}$ NAA after 6 weeks of culture (Table 1; Fig. 1c, 1d). Adenyl sulphate along with BAP and kinetin showed higher rate of shoot bud elongation and regeneration (Fig. 1d).

Table.1 Effect of various concentrations of auxin and cytokinin in callus development

\begin{tabular}{|c|c|c|c|c|c|c|}
\hline \multicolumn{3}{|c|}{ Growth regulators } & \multirow{2}{*}{$\begin{array}{c}\text { Responding } \\
\text { Explant } \\
(\%)(\text { mean } \pm \text { SE })\end{array}$} & \multirow{2}{*}{$\begin{array}{c}\text { Callus } \\
\text { Diameter } \\
(\mathbf{m m}) \\
(\text { mean } \pm \text { SE })\end{array}$} & \multirow{2}{*}{$\begin{array}{c}\text { Regeneration } \\
\text { Frequency } \\
(\%)(\text { mean } \pm \text { SE })\end{array}$} & \multirow{2}{*}{$\begin{array}{c}\text { Number of } \\
\text { shoots } \\
\text { Per explants } \\
\text { (mean } \pm \text { SE) }\end{array}$} \\
\hline $\begin{array}{c}\text { BAP } \\
(\mathrm{mg} / \mathrm{l})\end{array}$ & $\begin{array}{c}\text { NAA } \\
(\mathrm{mg} / \mathrm{l})\end{array}$ & $\begin{array}{c}\text { IAA } \\
(\mathrm{mg} / \mathrm{l})\end{array}$ & & & & \\
\hline $\mathbf{0}$ & 0 & 0 & n.d & n.d & n.d & n.d \\
\hline 0.5 & 0 & 0 & $75 \pm 2.11$ & $4.6 \pm 0.58$ & $48.6 \pm 3.23$ & $0.84 \pm 0.26$ \\
\hline 1.0 & 0 & 0 & $80 \pm 3.41$ & $5.1 \pm 0.33$ & $54.4 \pm 3.54$ & $1.22 \pm 0.45$ \\
\hline 1.5 & 0 & 0 & $82 \pm 3.62$ & $5.4 \pm 0.61$ & $61.1 \pm 3.84$ & $2.6 \pm 0.32$ \\
\hline 2.0 & 0 & 0 & $88 \pm 4.56$ & $5.9 \pm 0.43$ & $68.2 \pm 2.96$ & $3.8 \pm 0.51$ \\
\hline 2.5 & $\mathbf{0}$ & $\mathbf{0}$ & $90 \pm 5.62$ & $6.5 \pm 1.23$ & $83.4 \pm 3.33$ & $4.3 \pm 0.43$ \\
\hline 3.0 & 0 & 0 & $85 \pm 4.21$ & $6.7 \pm 1.25$ & $72.1 \pm 2.13$ & $3.1 \pm 0.31$ \\
\hline 0.5 & 0.5 & 0 & $70 \pm 5.12$ & $6.5 \pm 1.69$ & $58.8 \pm 1.94$ & $1.3 \pm 0.22$ \\
\hline 1.0 & 0.5 & 0 & $74 \pm 4.86$ & $6.9 \pm 1.87$ & $52.4 \pm 3.15$ & $2.1 \pm 0.29$ \\
\hline 1.5 & 0.5 & 0 & $76 \pm 3.61$ & $7.2 \pm 2.15$ & $74.3 \pm 3.26$ & $3.8 \pm 0.46$ \\
\hline 2.0 & 0.5 & 0 & $83 \pm 3.46$ & $7.6 \pm 1.22$ & $64.6 \pm 2.33$ & $3.6 \pm 0.38$ \\
\hline 2.5 & 0.5 & 0 & $86 \pm 4.12$ & $8.7 \pm 1.56$ & $79.8 \pm 3.33$ & $4.1 \pm 0.54$ \\
\hline 3.0 & 0.5 & 0 & $92 \pm 4.48$ & $8.2 \pm 1.56$ & $82 \pm 3.12$ & $4.4 \pm 0.52$ \\
\hline 0.5 & 0 & 1.0 & $67 \pm 2.16$ & $6.8 \pm 0.33$ & n.d & n.d \\
\hline 1.0 & 0 & 1.0 & $72 \pm 2.48$ & $6.4 \pm 0.53$ & n.d & n.d \\
\hline 1.5 & 0 & 1.0 & $76 \pm 3.12$ & $6.9 \pm 0.46$ & n.d & n.d \\
\hline 2.0 & 0 & 1.0 & $83 \pm 3.51$ & $7.1 \pm 1.26$ & n.d & n.d \\
\hline 2.5 & 0 & 1.0 & $89 \pm 4.56$ & $7.9 \pm 1.56$ & n.d & n.d \\
\hline 3.0 & 0 & 1.0 & $84 \pm 4.21$ & $7.6 \pm 1.85$ & n.d & n.d \\
\hline \multicolumn{3}{|c|}{$\mathrm{CD}(\mathrm{p}=0.05)$} & 3.78 & 0.64 & 3.42 & 0.18 \\
\hline
\end{tabular}


Table.2 Effect of plant growth regulators (PGRs) on shoot bud regeneration from cotyledon explants of $V$. radiata var. IPM-02-03 after sub-culturing

\begin{tabular}{|c|c|c|c|c|c|c|c|c|}
\hline \multicolumn{5}{|c|}{ MS + growth regulators (mg/l) } & \multirow{2}{*}{$\begin{array}{c}\% \text { of shoot } \\
\text { bud } \\
\text { regeneration } \\
(\text { mean } \pm \text { SE) }\end{array}$} & \multirow{2}{*}{$\begin{array}{c}\text { No. of } \\
\text { shoots/culture } \\
(\text { mean } \pm \text { SE) }\end{array}$} & \multirow{2}{*}{$\begin{array}{l}\text { Days required to } \\
\text { shoot induction } \\
\text { (mean } \pm \mathrm{SE})\end{array}$} & \multirow{2}{*}{$\begin{array}{l}\text { Shoot length }(\mathrm{cm}) \\
\text { after } 6 \text { weeks of } \\
\text { culture }(\text { mean } \pm \text { SE) }\end{array}$} \\
\hline $\begin{array}{c}\mathrm{Kn} \\
(\mathrm{mg} / \mathrm{l})\end{array}$ & $\begin{array}{c}\text { BAP } \\
(\mathrm{mg} / \mathrm{l})\end{array}$ & $\begin{array}{l}\text { NAA } \\
(\mathbf{m g} / \mathbf{l})\end{array}$ & $\underset{(\mathrm{mg} / \mathrm{l})}{\mathrm{IAA}}$ & $\begin{array}{c}\text { Adenine } \\
\text { sulfate }(\mathrm{mg} / \mathrm{l})\end{array}$ & & & & \\
\hline 0.0 & 0.0 & 0.0 & 0.0 & 0.0 & 0.0 & 0.0 & 00 & 00 \\
\hline 0.5 & 0.0 & 0.0 & 0.0 & 0.0 & 0.0 & 0.0 & 00 & 00 \\
\hline 1.0 & 0.0 & 0.0 & 0.0 & 0.0 & $11.5 \pm 0.8$ & $1.50 \pm 0.5$ & $32.5 \pm 0.5$ & $0.75 \pm 0.3$ \\
\hline 1.5 & 0.0 & 0.0 & 0.0 & 0.0 & $18.2 \pm 1.2$ & $1.25 \pm 0.6$ & $31.6 \pm 0.4$ & $2.30 \pm 0.23$ \\
\hline 2.0 & 0.0 & 0.0 & 0.0 & 0.0 & $22.8 \pm 1.4$ & $2.75 \pm 0.7$ & $29.4 \pm 0.6$ & $2.50 \pm 0.18$ \\
\hline 3.0 & 0.0 & 0.0 & 0.0 & 0.0 & $16.2 \pm 1.2$ & $1.88 \pm 0.4$ & $28.1 \pm 0.9$ & $2.62 \pm 0.41$ \\
\hline 4.0 & 0.0 & 0.0 & 0.0 & 0.0 & $8.4 \pm 0.76$ & $1.12 \pm 0.5$ & $34.4 \pm 1.2$ & $1.60 \pm 0.26$ \\
\hline 2.0 & 0.0 & 1.0 & 0.0 & 0.0 & $32.4 \pm 1.0$ & $2.76 \pm 0.5$ & $27.5 \pm 0.93$ & $1.92 \pm 0.35$ \\
\hline 2.0 & 0.0 & 1.5 & 0.0 & 0.0 & $34.5 \pm 1.2$ & $2.25 \pm 0.5$ & $28.4 \pm 0.7$ & $2.9 \pm 0.21$ \\
\hline 3.0 & 0.0 & 1.5 & 0.0 & 0.0 & $17.6 \pm 1.4$ & $2.56 \pm 0.3$ & $36.4 \pm 0.6$ & $2.6 \pm 0.67$ \\
\hline 0.0 & 1.0 & 0.0 & 0.0 & 0.0 & $14.6 \pm 0.9$ & $2.13 \pm 0.2$ & $34.68 \pm 0.9$ & $3.4 \pm 0.46$ \\
\hline 0.0 & 2.0 & 0.0 & 0.0 & 0.0 & $34.2 \pm 1.1$ & $2.45 \pm 0.5$ & $28.3 \pm 0.72$ & $3.5 \pm 0.43$ \\
\hline 0.0 & 3.0 & 0.0 & 0.0 & 0.0 & $42.8 \pm 1.3$ & $2.56 \pm 0.3$ & $30.3 \pm 0.6$ & $2.9 \pm 0.72$ \\
\hline 0.0 & 4.0 & 0.0 & 0.0 & 0.0 & $36.7 \pm 0.9$ & $1.81 \pm 0.4$ & $31.4 \pm 0.82$ & $2.4 \pm 0.44$ \\
\hline 0.0 & 2.0 & 1.5 & 0.0 & 0.0 & $68.3 \pm 1.4$ & $3.32 \pm 0.8$ & $28.4 \pm 0.91$ & $3.9 \pm 0.26$ \\
\hline 0.0 & 3.0 & 1.5 & 0.0 & 0.0 & $66.6 \pm 1.2$ & $3.54 \pm 0.9$ & $29.6 \pm 0.6$ & $3.7 \pm 0.48$ \\
\hline 0.0 & 2.0 & 2.0 & 0.0 & 0.0 & $62.8 \pm 1.3$ & $5.85 \pm 0.9$ & $17.8 \pm 0.41$ & $3.1 \pm 0.29$ \\
\hline 0.0 & 3.0 & 2.0 & 0.0 & 0.0 & $54.4 \pm 1.3^{b}$ & $4.21 \pm 0.8$ & $18.6 \pm 0.64$ & $3.2 \pm 0.34$ \\
\hline 0.0 & 2.0 & 1.5 & 0.0 & 25.0 & $72.4 \pm 1.0$ & $7.8 \pm 0.82$ & $15.26 \pm 0.9$ & $4.75 \pm 0.25$ \\
\hline 0.0 & 2.0 & 1.5 & 0.0 & 50.0 & $67.8 \pm 0.9$ & $6.32 \pm 0.9$ & $17.8 \pm 0.6$ & $3.9 \pm 0.35$ \\
\hline 0.0 & 3.0 & 1.5 & 0.0 & 25.0 & $64.5 \pm 1.2$ & $6.16 \pm 0.8$ & $31.4 \pm 0.8$ & $3.5 \pm 0.51$ \\
\hline 0.0 & 3.0 & 1.5 & 0.0 & 50.0 & $66.8 \pm 1.5$ & $6.38 \pm 1.0$ & $33.2 \pm 0.6$ & $2.6 \pm 0.24$ \\
\hline 0.0 & 2.0 & 0.0 & 1.5 & 0.0 & $41.5 \pm 0.8$ & $3.82 \pm 0.6$ & $38.1 \pm 1.1$ & $1.46 \pm 0.33$ \\
\hline 0.0 & 2.0 & 0.0 & 2.0 & 0.0 & $45.4 \pm 1.3$ & $2.88 \pm 0.7$ & $36.4 \pm 1.2$ & $1.35 \pm 0.33$ \\
\hline \multicolumn{5}{|c|}{$\mathrm{CD}(\mathrm{p}=\mathbf{0 . 0 5})$} & 4.23 & 0.18 & 0.28 & 0.26 \\
\hline
\end{tabular}


Table.3 Effect of different concentrations of auxins on root induction from excised shoots of $V$. radiata var. IPM-02-03

\begin{tabular}{|c|c|c|c|c|c|c|}
\hline \multicolumn{3}{|c|}{$1 / 2 \mathrm{MS}+$ growth regulators $(\mathrm{mg} / \mathrm{l})$} & \multirow{2}{*}{$\begin{array}{l}\text { Days to } \\
\text { rooting }\end{array}$} & \multirow{2}{*}{$\begin{array}{l}\% \text { of rooting } \\
(\text { mean } \pm S E)\end{array}$} & \multirow[t]{2}{*}{ Types of root } & \multirow{2}{*}{$\begin{array}{l}\text { Root length }(\mathrm{cm}) \\
\quad(\text { mean } \pm \text { SE })\end{array}$} \\
\hline $\begin{array}{c}\text { IAA } \\
(\mathrm{mg} / \mathrm{I})\end{array}$ & $\begin{array}{c}\text { IBA } \\
(\mathrm{mg} / \mathrm{l})\end{array}$ & $\begin{array}{l}\text { NAA } \\
(\mathbf{m g} / \mathbf{l})\end{array}$ & & & & \\
\hline 0.0 & 0.0 & 0.0 & 0.0 & 0.0 & - & 0.0 \\
\hline 0.1 & 0.0 & 0.0 & $11-12$ & $25.8 \pm 1.2$ & Short, thick & $0.56 \pm 0.05$ \\
\hline 0.25 & 0.0 & 0.0 & $11-12$ & $30.2 \pm 1.6$ & Short, thin & $0.84 \pm 0.04$ \\
\hline 0.50 & 0.0 & 0.0 & $13-14$ & $32.8 \pm 1.3 \mathrm{~b}$ & Short, thick, single & $1.96 \pm 0.03$ \\
\hline 0.0 & 0.1 & 0.0 & 9.0 & $46.2 \pm 2.5$ & Short, thin & $2.46 \pm 0.05$ \\
\hline 0.0 & 0.25 & 0.0 & $9-10$ & $56.8 \pm 2.6$ & Long, thin, & $2.94 \pm 0.05$ \\
\hline 0.0 & 0.50 & 0.0 & $9-10$ & $62.4 \pm 3.2$ & Long, thin, single & $3.45 \pm 0.04$ \\
\hline 0.0 & 0.0 & 0.10 & $8-9$ & $67.2 \pm 3.4$ & Long, thin, & $3.65 \pm 0.07$ \\
\hline 0.0 & 0.0 & 0.25 & $8-9$ & $76.6 \pm 2.8$ & Long, thin, multiple branching & $4.32 \pm 0.06$ \\
\hline 0.0 & 0.0 & 0.50 & $8-9$ & $56.4 \pm 3.2$ & Long, thin, branching & $1.26 \pm 0.02$ \\
\hline 0.0 & 0.1 & 0.25 & $9-10$ & $64.4 \pm 2.7$ & Long, thin, branching & $1.38 \pm 0.02$ \\
\hline \multicolumn{3}{|c|}{$\mathrm{CD}(\mathrm{p}=0.05)$} & 0.45 & 3.27 & & 0.17 \\
\hline
\end{tabular}

Fig.1
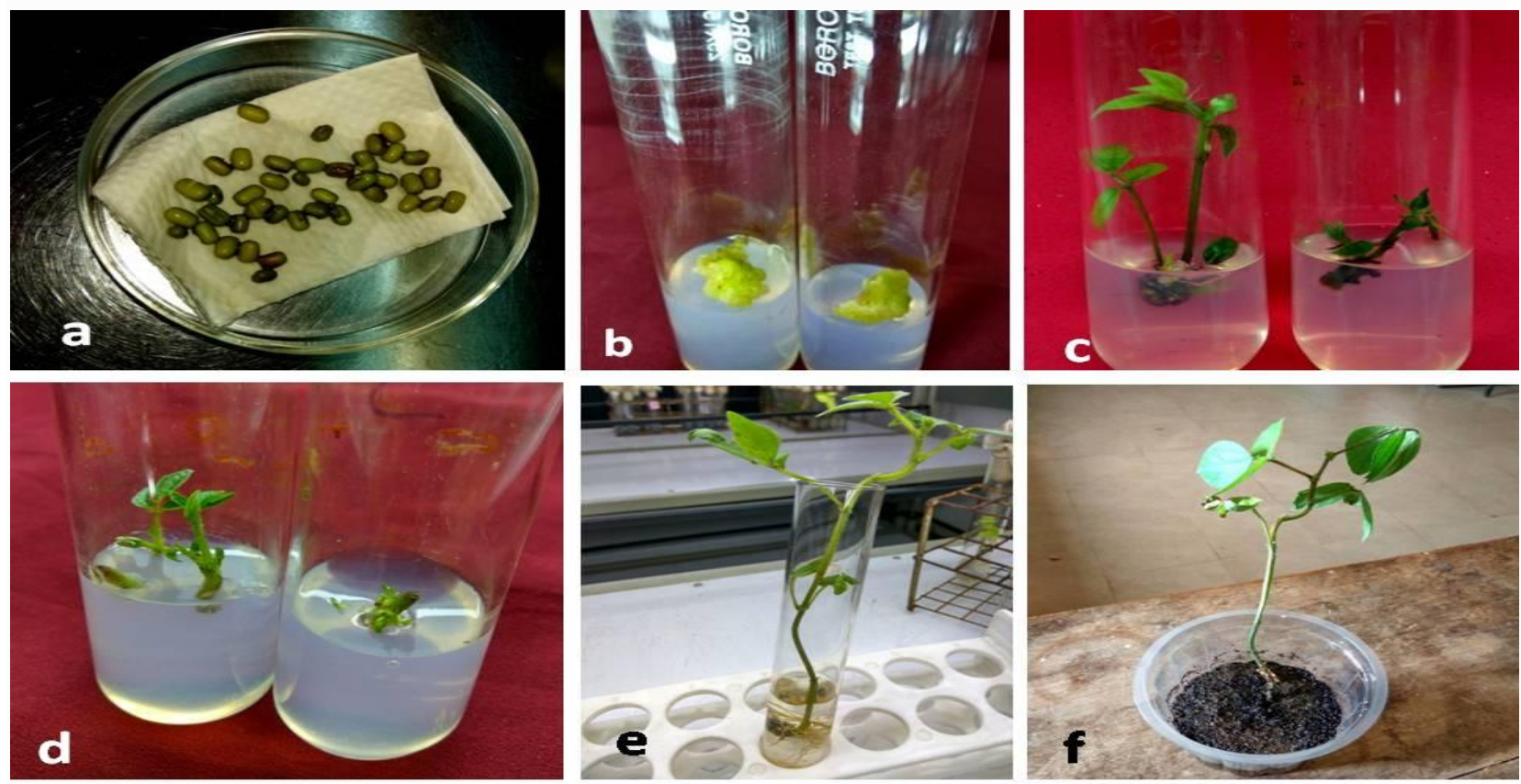

a. Seeds of green gram (Vigna radiata L. Wilczek) cv. IPM-02-03.

b. Development of callus from cotyledonary node of $V$. radiata grown on MS medium supplemented with $2.0 \mathrm{mg} / \mathrm{l}$ BAP and $1.5 \mathrm{mg} / \mathrm{l} \mathrm{NAA}$ after 4 weeks of subculture.

c. Development of shoot buds from cotyledon derived callus of $V$. radiata grown on MS medium supplemented with $2.0 \mathrm{mg} / \mathrm{l} \mathrm{BAP}$ and $1.5 \mathrm{mg} / \mathrm{l} \mathrm{NAA}$ after 8 weeks of subculture.

d. Direct development of shoot buds from cotyledonary node of $V$. radiata without callus phase grown on MS medium supplemented with $1.0 \mathrm{mg} / \mathrm{l} \mathrm{BAP}$ and $1.0 \mathrm{mg} / \mathrm{l} \mathrm{NAA}$ after 8 weeks of subculture.

e. Proliferation of roots from excised shoots of $V$. radiata grown on MS medium supplemented with $0.25 \mathrm{mg} / \mathrm{l} \mathrm{NAA}$ after 8 days of culture.

f. Rooted plantlets kept in sterile distilled water before transfer to pot.

f. Rooted plantlets establish in soil with normal growth before transplanted in field. 
The maximum multiple shoot production was obtained from cotyledonary node when cultured in MS media fortified with $1.5 \mathrm{mg} / \mathrm{l}$ BAP and $1.0 \mathrm{mg} / \mathrm{l}$ kinetin. Shoot multiplication and propagation of green gram have also been reported by different workers using different explants (Sagare et al., 2015; Khatun et al., 2008; Vijayan et al., 2006; Gulati et al., 1990). Increased BAP concentration from 2.0 to $3.0 \mathrm{mg} / \mathrm{l}$, the rate of shoot bud regeneration increased but the shoot growth was reduced.

Higher concentration more than $4.0 \mathrm{mg} / \mathrm{l} \mathrm{BAP}$ and kinetin more than $2.0 \mathrm{mg} / \mathrm{l}$ showed reduced shoot bud regeneration. It was observed that BAP enhances regeneration frequency irrespective of the basal medium and nature of explants and similar findings were also reported by Gulati and Jaiwal (1990); Yadav et al., (2010) and Shiv Kumar (2010).

The cultures were initially incubated for 2 weeks in dark and subsequently transferred to $16 \mathrm{~h}$ photoperiod, which showed higher rate of shoot multiplication as compared with the cultures incubated in completely $16 \mathrm{~h}$ photoperiod. The cytokinin has significant effect on shoot multiplication as reported earlier in other legume crops like chickpea and black gram (Yadav et al., 2010; Mony et al., 2010; Das et al., 2002). In the present study, the maximum (7.80) number of shoot buds/culture was obtained within weeks culture on MS medium supplemented with $2 \mathrm{mg} / \mathrm{l} \mathrm{BAP}+1.5 \mathrm{mg} / \mathrm{l} \mathrm{NAA}+25 \mathrm{mg} / \mathrm{l}$ Ads (Table 2). Muruganantham et al., (2005) reported that the multiple shoot induction (6 shoot buds/explant) was obtained from axillary shoots on medium having $1.0 \mathrm{mg} / \mathrm{l}$ BAP. Mony et al., (2010) reported that the lowering of BAP concentration $(1.0 \mathrm{mg} / \mathrm{l})$ produced maximum number of shoots (9.33) in case of black gram also stated that the increased BAP concentration in medium resulted callus formation. Well-developed rooting system is necessary for better establishment of the plantlet in the field. Healthy shoots were cultured on different root induction media (half strength MS medium supplemented with IAA or IBA or NAA) alone as well as in combination for root induction. Root initiation was not achieved on medium without growth regulators. Root initiation developed in half-strength MS medium supplemented with $0.1-0.25 \mathrm{mg} / \mathrm{l}$ NAA or IBA after 8 to 10 days of culture (Fig. 1e). The medium having NAA showed better root formation as compared with IBA (Table 3). The medium having both IBA and NAA resulted in low percentage of rooting and formation of globular callus at the cut end. The percentage of rooting varied from 25.8 to $76.6 \%$ depending on growth regulators used. The roots were branched, thin and elongated. However, IBA was effective for root induction as reported by Das et al., (2002), Geetha et al., (1998), Mony et al., (2010) found that percentage of rooting was higher in IBA but number of roots per plant was higher in NAA.

\section{Transplantation in soil}

The rooted plantlets were transferred to distilled water and kept for $72 \mathrm{~h}$ for acclimatization (Fig. 1e). Further, the plantlets were transferred to polythene bag containing soil: sand: vermi-compost $(1: 1: 1)$ and kept in the greenhouse for 15 days with $85 \%$ relative humidity $(\mathrm{RH})$. After 2 weeks, these plantlets were transferred to poly-house for hardening and final establishment (Fig. 1f). Survival percentage of the transplanted plantlets was $70-75 \%$. Further, the plantlets grew normally.

\section{Acknowledgments}

The authors wish to acknowledge to Department of Biotechnology, Govt of India 
for providing financial assistance for the present investigation. The authors also acknowledge Vice Chancellor, Orissa University of Agriculture and Technology, Bhubaneswar for proving necessary infrastructure and laboratory facilities for carry out the research work.

\section{References}

Adlinge, P. M., Samal, K. C., Kumarswamy, R. V. and Rout, G. R. 2014. Rapid in vitro plant regeneration of Blackgram (Vigna mungo L. Hepper) var Sarala, an important legume crop. Proc of Nat Aca Sci., Sect B Biological Science 84(3): 823-827.

Avenido, R. A. and Hautea, D. M. 1990. In vitro organogenesis and flowering in mung bean (Vigna radiata L. Wilczek). Philip J. crop Sci. 15(3): 169-173.

Chandra, A. and Pental, D. 2003. Regeneration and genetic transformation of grain legumes: an overview. Curr Sci. 84:381-387.

Das, D. K., Prasanna, B., Prakash, N. S and, Bhalla-Sarin, N. 2002. Improvement method of regeneration of black gram (Vigna mungo L.) through liquid culture. In Vitro Cell Dev Biol Plant. 38(5): 456-459.

De Candolle A. 1883. In: Laffitte J (ed) Origine des plantes cultivées. G. Bailliere et cie, Paris.

Dita, M. A., Rispail, N., Prats, E., Rubiales, D. and Singh, K. B. 2006. Biotechnology approaches to overcome biotic and abiotic stress constraints in legumes. Euphytica. 147: 1-24.

Eapen, S. 2008. Advances in development of transgenic pulse crops. Biotech Adv. 26:162-168.

Geetha, N., Venkatachalam, P. and Rao, G.R. 1998. In vitro plant regeneration from shoot tip culture of black gram (Vigna mungo L. Hepper). J Tropic Agric.
$36(1 / 2): 6-11$

Gulati, A. and Jaiwal, P. K. 1990. Culture conditions effecting plant regeneration from cotyledon of mungbean [Vigna radiata (L.) Wilczek]. Plant Cell Rep. 13:523-527.

Khatun, M. K., Haque, M. S., Islam, S. And Nasiruddin, M. 2008. In vitro regeneration of mung bean (Vigna radiata L.) from different explants. Progress. Agric. 19(2): 13-19.

Mony, S. A., Haque, M.D.S., Alam, M. D. M., Hasanuzzaman, M. and Nahar, K. 2010. Regeneration of black gram (Vigno mungo L.) on changes of hormonal condition. Not Bot Hort Agrobot Cluji, 38(3):140-145.

Murashige, T. and Skoog, F. 1962. A review medium for rapid growth and bioassays with tobacco tissue cultures. Physiol Plantarum. 15: 470-497.

Muruganantham, M., Ganapathi, A., Amutha, S., Vengadesan, G. and Selvaraj, N. 2005. Shoot regeneration from immature cotyledonary nodes in black gram (Vigna mungo(L.) Hepper). Indian J Biotechnol. 4: 551-555.

Pasquet, R. 2001. Vigna Savi In: Mackinder B, Pasquet R,Polhil Poly-R and Verdcourt B, (eds) Flora Zambesiaca, volume part phaseoleae. Royal Botanic Garden, Kew, pp-121-156.

Sagare, D. B. and Mohanty, I. C. 2015. In vitro Regeneration system Green Gram (Vigna radiata L. Wilczek cv Sujata): A recalcitrant legume. J Agril. Sci. 6(1): 64-67.

Sen, J. and Guha- Mukherjee, S. 1998. In vitro induction of multiple shoots and plant regeneration in Vigna, In vitro cell Dev Biol Plant. 34: 276-280.

Shivakumar, P., Gnanam, I. R., Ramakrishnan, K. and Manickam, A. 2010. Regeneration of Vigna radiata. Biologia Plant. 54(2):245-251.

Singh, B. B., Dixit, G. P. and Katiyar, P. K. 
2010. Vigna Reseach in India (25 years of research achievements). All India Coordinated Research Project MULLaRP, Kanpur, India.Indian Council of Agricultural Research, 158p. Singh, B. B., Dixit, G. P. and Katiyar, P. K. 2010. Vigna Reseach in India (25 years of research achievements). All India Coordinated Research Project MULLaRP, Kanpur, India. Indian Council of Agricultural Research, 158p.

Singh, D. P., Singh, B. B. and Pratap, A. 2016. Genetic improvement of mungbean and urdbean and their role in enhancing pulse production in India. Indian J. Genet., 76(4): 550567.Technology perspective. Indian J Genet 76(4):375-387.

Varalaxmi, Y., Vijaylaxmi, A., Yadav, S. K.,
Venketeswaralu, B. and Maheswari M. 2007. Efficient plant regeneration from cotyledons of black gram [Vigna mungo (L.) Hepper]. Indian J. Biotechnol., 6: 414-417.

Vijayan, S., Beena, M. R. and Kirti, P. B. 2006. Effective and simple regeneration of mungbean (Vigna radiata (L). Wilzcek) using cotyledonary node explants. J Plant Biochem Biotechnol 15:131-134.

Yadav, S. K., Sreenu, P., Maheswari, M., Vanaja, M. and Vekenteswaralu, B. 2010. Efficient shoot regeneration from double cotyledonary node explants of green gram (Vigna radiata (L). Wilzcek). Indian J. Biotechnol. 9: 403407.

\section{How to cite this article:}

Aparna Priyadarshini Patra, Kailash Chandra Samal, Gyana Ranjan Rout, Simachal Sahu and Prem Narayan Jagadev. 2018. In vitro Regeneration of Recalcitrant Green Gram (Vigna radiata L. Wilczek) from Immature Cotyledons for Genetic Improvement. Int.J.Curr.Microbiol.App.Sci. 7(01): 3072-3080. doi: https://doi.org/10.20546/ijcmas.2018.701.364 